\section{JURNAL EKONOMI EFEKTIF}

ISSN : $2622-8882$, E-ISSN : 2622-9935

Jurnal Ekonomi Efektif, Vol. 3, No. 4, Juli 2021

@ Prodi Manajemen Fakultas Ekonomi Universitas

Pamulang

\title{
PENGARUH KETERAMPILAN DAN STRESS KERJA TERHADAP PRODUKTIVITAS KARYAWAN PADA PT. PANCA TUNAS HARAPAN KOTA SORONG
}

\author{
M. Zein Asrori Taufik ${ }^{1 *}$, Retno Dewi Wijiastuti ${ }^{2}$ \\ Universitas Muhammadiyah Sorong, Papua Barat, Indonesia \\ zeinasrori97@gmail.com*
}

Manuskrip: Mei -2021 Ditinjau: Mei -2021; Diterima: Juni-2021; Online: Juli-2021; Diterbitkan: Juli-2021

\begin{abstract}
ABSTRAK
Penelitian ini bertujuan untuk mengetahui pengaruh keterampilan terhadap produktivitas karyawan pada PT. Tunas Panca Harapan Kota Sorong. Penelitian ini menggunakan metode deskriptif dan korelasi dengan menggunakan pendekatan kuantutatif. Populasi penelitian ini adalah karyawan yang bekerja pada PT. Panca Tunas Harapan Kota Sorong yang berjumlah 35 orang. Teknik pengumpulan sampel penelitian ini menggukan sampel jenuh dengan sampel 35 orang. Teknik pengumpulan data dengan menyebarkan kuisioner. Hasil penelitian menunjukkan bahwa keterampilan berpengaruh secara positif terhadap produktvitas karyawan pada PT. Panca Tunas Harapan Kota Sorong. Hal ini dibuktikan dengan nilai signifikan sebesar $0.000<$ dari taraf nilai signifikassi 0.05 .
\end{abstract}

\section{Kata Kunci: Keterampilan, Stres Kerja, Produktivitas Karyawan}

\begin{abstract}
This study aims to determine the effect of skills and work stress on employee productivity at PT. Panca Tunas Harapan Soronng City. This study uses descriptive and correlation methods using a quantitative approach. The population of this study are employees who work at PT. Panca Tunas Harapan Sorong City, totaling 35 people. The sampling technique of this study used a saturated sample with a sample of 35 people. Data collection techniques by distributing questionnaires. The results showed that skills and work stress had a simultaneous (together) effect on employee productivity at PT. Panca Tunas Harapan Sorong City. This is evidenced by a significant value of $0.000<$ from the level of significance value of 0.05 .
\end{abstract}

Keywords: Skills, Job Stress, Employee Productivity 


\section{PENDAHULUAN}

\section{A. Latar Belakang}

PT. Panca Tunas Harapan Kota Sorong merupakan salah satu mitra BUMN Telkomsel yang ada di Kota Sorong dengan menyediakan berbagai layanan produk telkomsel berupa pulsa biasa, pulsa paket, dan lainnya. Dalam meningkatkan perkembangan perusahaan tentunya dilihat dari produktivitas pada PT. Panca Tunas Harapan Kota Sorong itu sendiri.

Menurut (Sutrisno, 2014) produktivitas kerja merupakan rasiodari hasil kerja dengan waktu yang dibutuhkan untuk menghasilkan barang atau jasa. Sedangkan menurut Siagian dalam Agustin (2014) Produktivitas kerja adalah kemampuan menghasilkan barang/jasa dari berbagai sumber daya dan kemampuan yang dimiliki oleh setiap pekerja/karyawan.

Produktivitas yang baik tentunya di tunjang keterampilan yang baik juga, Keterampilan kerja berhubungan erat dengan kemampuan untuk mampu melaksanakan tugas-tugas fisik dan mental (Suwatno, 2013). Sedangkan menurut Reber dalam Muhibbin (2013:56) Keterampilan adalah kemampuan melakukan pola-pola tingkah laku yang kompleks dan tersusun secara mulus dan sesuai dengan keadaan untuk mencapai hasil tertentu.yang mana Keterampilan yang memadai tentunya meningkatkan hasil produktivitas nya (SALIM \& RAWI, 2020).

Stres dalam pekerjaan merupakan hal yang sering dialami oleh setiap pegawai apa lagi menyangkut pekerjaan-pekerjaan yang berat. Stres sendiri memiliki arti sebagai suatu kondisi yang menekan keadaan psikis seseorang dalam mencapai suatu kesempatan dimana untuk mencapai kesempatan tersebut terdapat batasan atau penghalang (Robbins, 2008).

Produktivitas karyawan pada PT. Panca Tunas Harapan Kota Sorong di pengaruhi oleh keterampilan dan stres kerja. Untuk mewujudkan Produktivitas yang tinggi tentunya di tunjang dengan keterampilan yang dimiliki karyawan pada perusahaan tersebut. Kurangnya kemampuan dalam bekerja, kemampuan dalam mengendalikan emosional serta komitmen dalam pekerjaan yang berdampak pada keterampilan kerja dan tuntutan peran seperti kurangnya fasilitas yang memadai, serta tuntutan kerja yang harus di penuhi mengakibatkan stres kerja sehingga mempengaruhi produktivitas karyawan pada perusahaan itu sendiri.

Berdasarkan uraian diatas maka peneliti tertarik untuk melakukan penelitian "Pengaruh Keterampilan dan Stres Kerja Terhadap Produktivitas Karyawan Pada PT. Panca Tunas Harapan Kota Sorong”.

\section{B. Rumusan Masalah}

1. Apakah keterampilan kerja berpengaruh secara parsial terhadap kinerja karyawan pada PT. Panca Tunas Harapan Kota Sorong?

2. Apakah stres kerja karyawan berpengaruh secara parsial terhadap kinerja karyawan pada PT. Panca Tunas Harapan Kota Sorong?

3. Apakah keterampilan dan stres kerja karyawan berpengaruh secara simultan terhadap kinerja karyawan pada PT. Panca Tunas Harapan Kota Sorong?

\section{Tujuan Penelitian}

1. Untuk mengetahui pengaruh keterampilan terhadap kinerja karyawan pada PT. Panca Tunas Harapan Kota Sorong.

2. Untuk mengetahui pengaruh stres kerja karyawan terhadap kinerja karyawan pada PT. Panca Tunas Harapan Kota Sorong. 
3. Untuk mengetahui pengaruh keterampilan dan stress kerja kayawan terhadap kinerja karyawan pada PT. Panca Tunas Harapan Kota Sorong.

\section{METODE PENELITIAN}

\section{Populasi}

Populasi dalam penelitian ini berjumlah 35 responden karyawan pada PT. Panca Tunas Harapan Kota Sorong.

\section{Sampel}

Sampel dalam penelitian ini berjumlah 35 responden karyawan pada PT. Panca Tunas Harapan Kota Sorong

\section{Jenis Penelitian}

Dalam penelitian ini menggunakan jenis penelitian dengan metode kuantitatif, deskriptif dengan pendekatan kolerasi. Metode kuantitatif merupakan penelitian dengan menguji hasil penelitian yang berupa data dalam bentuk angka dengan analisis menggunakan statistic (Sugiyono, 2016).

\section{Metode Analisis Data}

Dalam menganalisis data digunakan uji instrumen, uji asumsi klasik, regresi, koefisien determinasi dan uji hipotesis.

\section{HASIL PENELITIAN DAN PEMBAHASAN}

\section{Analisis Deskriptif}

Pada pengujian ini digunakan untuk mengetahui skor minimum dan maksimum, mean score dan standar deviasi dari masing-masing variabel. Adapun hasilnya sebagai berikut:

\begin{tabular}{|c|c|c|c|c|c|}
\hline \multicolumn{6}{|c|}{$\begin{array}{c}\text { Tabel 1. Hasil Analisis Descriptive Statistics } \\
\text { Descriptive Statistics }\end{array}$} \\
\hline & $\mathrm{N}$ & Minimum & Maximum & Mean & Std. Deviation \\
\hline Keterampilan (X1) & 35 & 15 & 25 & 19.46 & 2.417 \\
\hline Stres Kerja (X2) & 35 & 14 & 24 & 17.20 & 2.784 \\
\hline $\begin{array}{l}\text { Produktivitas } \\
\text { Karyawan(Y) }\end{array}$ & 35 & 15 & 25 & 20.97 & 2.320 \\
\hline Valid N (listwise) & 35 & & & & \\
\hline
\end{tabular}

Keterampilan diperoleh varians minimum sebesar 15 dan varians maximum 25 dengan mean score sebesar 19,46 dengan standar deviasi 2,417.

Stres kerja diperoleh varians minimum sebesar 14 dan varians maximum 24 dengan mean score sebesar 19,46 dengan standar deviasi 2,784.

Produktivitas karyawan diperoleh varians minimum sebesar 15 dan varians maximum 25 dengan mean score sebesar 20,97 dengan standar deviasi 2,320.

\section{Analisis Verifikatif}

Pada analisis ini dimaksudkan untuk mengetahui pengaruh variabel independen terhadap variabel dependen. Adapun hasil pengujian sebagai berikut:

\section{a. Analisis Regresi Linier Berganda}

Uji regresi ini dimaksudkan untuk mengetahui perubahan variabel dependen jika variabel independen mengalami perubahan. Adapun hasil pengujiannya sebagai berikut:

Tabel 2. Hasil Pengujian Regresi Linier Berganda

\begin{tabular}{cccccc}
\hline \multicolumn{5}{c}{} & \multicolumn{4}{c}{ Coefficients $^{\mathbf{a}}$} \\
& $\begin{array}{c}\text { Unstandardized } \\
\text { Coefficients }\end{array}$ & $\begin{array}{l}\text { Standardized } \\
\text { Coefficients }\end{array}$ & & \\
\cline { 2 - 5 } Model & B & $\begin{array}{c}\text { Std. } \\
\text { Error }\end{array}$ & Beta & t & Sig. \\
\hline
\end{tabular}




\begin{tabular}{|c|c|c|c|c|c|}
\hline (Constant) & 5.370 & 2.829 & & 1.898 & .067 \\
\hline Keterampilan & .711 & .113 & .741 & 6.300 & .000 \\
\hline Stres Kerja & .103 & .098 & .123 & 1.046 & .303 \\
\hline
\end{tabular}

a. Dependent Variable: Produktivitas Karyawan

Berdasarkan hasil pengujian pada tabel di atas, diperoleh persamaan regresi $\mathrm{Y}$ $=5,370+0,711 \mathrm{X} 1+0,103 \mathrm{X} 2$. Dari persamaan tersebut dijelaskan sebagai berikut:

1) Konstanta sebesar 5,370 artinya jika Keterampilan dan Stres kerja tidak ada maka Produktivitas karyawan sebesar 5,570.

2) Koefisien Regresi X1 sebesar 0,711 artinya setiap Keterampilan yang dimiliki karyawan akan meningkatkan Produktivitas karyawan sebesar 0,711. Dan sebaliknya, jika keterampilan yabg dimiliki karyawan dalam bekerja menurun maka, akan menurunkan Produktivitas karyawan sebesar 0,711, dengan anggapan bahwa X1 tetap.

3) Koefisien Regresi $X 2$ sebesar 0,103 artinya setiap terjadi Stres Kerja akan menurunkan Produktivitas karyawan sebesar 0,103. Dan sebaliknya bila Stres dalam bekerja menurun maka akan menaikkan ProduktivitasKaryawan sebesar 0,426 dengan anggapan bahwa X1 tetap. Tanda (+) menunjukkan arah hubungan yang searah sedangkan tanda (-) menunjukkan arah hubungan yang berbanding terbalik antar variabel independen $(\mathrm{X})$ dengan variabel dependen $\mathrm{Y}$.

\section{b. Analisis Koefisien Determinasi}

Analisis koefisien determinasi dimaksudkan untuk mengetahui besarnya persentase pengaruh dari variabel independen terhadap variabel dependen baik secara parsial maupun simultan. Adapun hasil pengujian sebagai berikut:

Tabel 3. Hasil Pengujian Koefisien Determinasi Keterampilan dan stres kerja terhadap produktivitas karyawan

\begin{tabular}{lcccc}
\hline \multicolumn{4}{c}{ Model Summary $^{\mathbf{b}}$} \\
\hline & & & Std. \\
& & & $\begin{array}{c}\text { Adjusted } \\
\text { Error of } \\
\text { the }\end{array}$ \\
Model & $\mathrm{R}$ & R Square & R Square & Estimate \\
\hline 1 & $.747^{\text {a }}$ & .558 & .530 & 1.590 \\
\hline a. Predictors: (Constant), Stres Kerja, Keterampilan \\
b. Dependent Variable: Produktivitas Karyawan
\end{tabular}

Dari table koefisie dterminasu di atas, dapat dilihat bahwa angka koefisien korelasi (R) sebesar 0,747. Hal ini berarti hubungan antara variabel independen dan dependen sebesar 74,7\%. Dari angka tersebut dapat diambil kesimpulan bahwa hubungan antara variabel keterampilan dan stres kerja dengan produktivitas karyawan sangat kuat. Besarnya Adjust $\mathrm{R}$ Squar $\left(\mathrm{R}^{2}\right)$ adalan 0,588.

Hasil perhitungan statistik ini berarti bahwa kemampuan variabel independen dalam menerangkan variasinya perubahan variable dependen sebesar 55,8\%, Sedangkan sisanya di pengaruhi oleh faktor lainnya.

\section{c. Uji Hipotesis}

\section{Uji hipotesis Parsial (Uji t)}

Pengujian hipotesis dengan uji t digunakan untuk mengetahui hipotesis parsial mana yang diterima.

Hipotesis pertama: Terdapat pengaruh yang signifikan antara lingkungan kerja terhadap kinerja karyawan. 
Tabel 4. Hasil Uji Hipotesis Keterampilan Terhadap Produktivitas Karyawan.

\begin{tabular}{|c|c|c|c|c|c|}
\hline \multicolumn{6}{|c|}{ Coefficients $^{\mathrm{a}}$} \\
\hline \multirow[b]{2}{*}{ Model } & $\begin{array}{l}\text { Unstan } \\
\text { Coeff }\end{array}$ & $\begin{array}{l}\text { dized } \\
\text { ents }\end{array}$ & $\begin{array}{l}\text { Standardized } \\
\text { Coefficients }\end{array}$ & \multirow[b]{2}{*}{$\mathrm{T}$} & \multirow[b]{2}{*}{ Sig. } \\
\hline & B & $\begin{array}{l}\text { Std. } \\
\text { Error }\end{array}$ & Beta & & \\
\hline $\begin{array}{ll}1 & \text { (Constant) }\end{array}$ & 7.217 & 2.215 & & 3.259 & .003 \\
\hline Keterampilan & .707 & .113 & .737 & 6.258 & .000 \\
\hline
\end{tabular}

a. Dependent Variable: Produktivitas Karyawan

Berdasarkan hasil pengujian pada tabel di atas, terlihat variable keterampilan dengan nilai signifikasnsi $0.000<0,05$ yang berarti $\mathrm{H} 1$ di terima, dapat di simpulkan ada pengaruh secara signifikan variable keterampilan terhadap produktivitas karyawan pada PT. Tunas Panca Harapan.

Tabel 5. Hasil Uji Hipotesis Stres Kerja Terhadap Produktivitas Karyawan.

\begin{tabular}{|c|c|c|c|c|c|}
\hline \multirow[b]{3}{*}{ Model } & \multicolumn{3}{|c|}{ Coefficients $^{\mathrm{a}}$} & \multirow[b]{3}{*}{$\mathrm{T}$} & \multirow[b]{3}{*}{ Sig. } \\
\hline & \multicolumn{2}{|c|}{ Coefficients } & $\begin{array}{l}\text { Standardized } \\
\text { Coefficients }\end{array}$ & & \\
\hline & B & $\begin{array}{c}\text { Std. } \\
\text { Error }\end{array}$ & Beta & & \\
\hline 1 (Constant) & 19.588 & 2.514 & & 7.791 & .000 \\
\hline Stres Keria & .080 & .144 & .097 & .557 & .581 \\
\hline
\end{tabular}

a. Dependent Variable: Produktivitas Karyawan

Berdasarkan hasil pengujian pada tabel di atas, terlihat variable stres kerja dengan nilai signifikasnsi $0.581>0,05$ yang berarti $\mathrm{H} 2$ ditolak dapat di simpulkan tidak ada pengaruh secara signifikan variable stres kerja terhadap produktivitas karyawan pada PT. Tunas Panca Harapan Kota Sorong.

\section{Uji Hipotesis Simultan (Uji F)}

Pengujian hipotesis dengan uji $\mathrm{F}$ digunakan untuk mengetahui hipotesis simultan yang mana yang diterima.

Hipotesis ketiga Terdapat pengaruh yang signifikan antara lingkungan kerja dan kepemimpinan terhadap kinerja karyawan.

Tabel 6. Hasil Uji Hipotesis Keterampilan dan Stres Kerja Terhadap Produktivits

\section{Karyawan.}

\begin{tabular}{|c|c|c|c|c|c|c|}
\hline \multicolumn{7}{|c|}{ ANOVA $^{a}$} \\
\hline \multicolumn{2}{|c|}{ Model } & $\begin{array}{l}\text { Sum of } \\
\text { Squares }\end{array}$ & Df & $\begin{array}{l}\text { Mean } \\
\text { Square }\end{array}$ & $\mathrm{F}$ & Sig. \\
\hline 1 & Regression & 102.062 & 2 & 51.031 & 20.183 & $.000^{\mathrm{b}}$ \\
\hline & Residual & 80.909 & 32 & 2.528 & & \\
\hline & Total & 182.971 & 34 & & & \\
\hline
\end{tabular}

a. Dependent Variable: Produktivitas Karyawan

b. Predictors: (Constant), Stres Kerja, Keterampilan

Berdasarkan hasil pengujian pada tabel di atas, diperoleh di dapat $\mathrm{F}$ hitung sebesar 20,183 dengan probabilitas sebesar 0,000 yang nilainya dibawah 0,05. Hal ini menunjukkan bahwa semua variabel independen yaitu Keterampilan dan Stres Kerja berpengaruh signifikan secara simultan (bersama-sama) terhadap produktivitas karyawan pada PT. Tunas Panca Harapan. Dengan demikian, H3 diterima.

\section{Pembahasan Hasil Penelitian}

\section{Pengaruh Keterampilan Terhadap Produktivitas Karyawan}

Variable keterampilan berpengaruh secara signifikan terhadap produktivitas karyawan pada PT. Panca Tunas Harapa Kota Sorong. Hal ini dibuktikan dengan 
nilai sifnifikansi $0,000<$ taraf signifikansi 0,05 .

\section{Pengaruh Stres Kerja Terhadap Produktivitas}

Variabel stres kerja tidak berpengaruh secara signifikan terhadap produktivitas karyawan pada PT. Panca Tunas Harapan Kota Sorong. Hal ini dibuktkan dengan nilai signifikansi variable stres kerja $0.851>$ dari taraf siginifansi 0,05 .

\section{Pengaruh Keterampilan dan Stres Kerja Terhadap Produktivtas Karyawan}

Variable keterampilan dan stres kerja berpengaruh secara simultan (bersamasama) terhadap produktivitas karyawan pada PT. Panca Tunas Harapan Kota Sorong. Hal ini dapat di buktikan dengan hasil uji memperoleh nilai signifikansi $0,000<$ dari taraf nilai signifikansi 0,05 .

\section{KESIMPULAN DAN SARAN}

\section{Kesimpulan}

a. Variable keterampilan berpengaruh secara signifikan terhadap produktivitas karyawan pada PT. Panca Tunas Harapa Kota Sorong. Hal ini dibuktikan dengan nilai sifnifikansi $0,000<$ taraf signifikansi 0,05 .

b. Variabel stres kerja tidak berpengaruh secara signifikan terhadap produktivitas karyawan pada PT. Panca Tunas Harapan Kota Sorong. Hal ini dibuktkan dengan nilai signifikansi variable stres kerja $0.851>$ dari taraf siginifansi 0,05 .

c. Variable keterampilan dan stres kerja berpengaruh secara simultan (bersama-sama) terhadap produktivitas karyawan pada PT. Panca Tunas Harapan Kota Sorong. Hal ini dapat di buktikan dengan hasil uji memperoleh nilai signifikansi $0,000<$ dari taraf nilai signifikansi 0,05 .

\section{Saran}

a. Saran Praktis

Keterampilan berpengaruh secara signifikan terhadap produktivitas karyawan pada PT. Panca Tunas Harapan Kota Sorong. Hendaknya PT. Panca Tunas Harapan meningkatkan keterampilan karyawan demi menunjang produktivitas karyawan itu sendiri.

b. Saran Akademis

Bagi peneliti selanjutnya, diharapkan melakukan penelitian lebih luas mengenai keterampilan dan stres kerja terhadap produktivitas karyawan dengan menambah sampel yang ada dan menambah variable-variabel yang mempengaruhi produktivitas karyawan.

\section{DAFTAR PUSTAKA}

Robbins, S. P. (2008). Perilaku Organisasi. Selemba Empat.

SALIM, A. O., \& RAWI, R. D. P. (2020). Pengaruh Jaminan Sosial Tenaga Kerja Terhadap Produktivitas Kerja Karyawan Pada Pt Sumber Abadi Indonesia Cabang Kota Sorong Papua Barat. Jurnal Ilmiah Manajemen “E $M \quad O \quad R$," $4(1), 32$. https://doi.org/10.32529/jim.v4i1.394

Sugiyono. (2016). Metode Penelitian Kuantitatif, Kualitatif dan R\&D. PT Alfabet.

Sutrisno, E. (2014). Manajemen Sumber Daya Manusia. Cetak Ke Enam. Pranada Media Group.

Suwatno, dan T. Y. (2013). Manajemen Sumber Daya Manusia. Alfabeta. 